Geosistemy perehodnykh zon = Geosystems of Transition Zones / Геосистемы переходных зон

Content is available under the Creative Commons Attribution 4.0 International License (CC BY 4.0)

2021, vol. 5, No. 1, pp. 55-59

URL: http://journal.imgg.ru/archive.html ; https://elibrary.ru/title about.asp?id=64191

https://doi.org/10.30730/gtrz.2021.5.1.055-059

LETTER TO THE EDITOR

\title{
On some aspects of the article «On the stress drop in North Eurasia earthquakes
} source-sites versus specific seismic energy»

Yuryi L. Rebetsky, ScopusID: 6508077756; SPIN-код: 6436-6302, reb@ifz.ru

Schmidt Institute of Physics of the Earth of the Russian Academy of Sciences, Moscow, Russia

Abstract PDF ENG Pезюме PDF RUS $\quad$ Full text PDF RUS

Abstract. In the article by N.A. Sycheva and L.M. Bogomolov On the stress drop in North Eurasia earthquakes source-sites versus specific seismic energy (Geosistemy perehodnykh zon = Geosystems of Transition Zones, 2020, vol. 5(1), p. 393-446. (In Russ. \& Engl.). https://doi.org/10.30730/gtrz.2020.4.4.393-416.417-446), the Authors proposed to combine the interrelated data on the stress drop in the earthquake sources, $\Delta \sigma$, and reduced seismic energy, e e on earthquake scale along with expansion of the measurement statistics (assessments). The dependence of these parameters of a source on the seismic moment or on the earthquake magnitude within $2.2 \leq \mathrm{M} \leq 4.0$ magnitude range has been determined using the example of the Northern Tien Shan (Bishkek geodynamic polygon with the KNET network). The Author of the letter to the editor notes the article conclusions to be limited, because such relationship is only manifested within the more or less narrow range of the magnitudes. Attention is also drawn to the semantic difference between the $\Delta \sigma$ and epR parameters. It is the reduced seismic energy that reflects the mean strain in the source area, and its appliance to the analysis of scale dependences of earthquake sources is more informative.

For citation: Rebetsky Yu.L. On some aspects of the article «On the stress drop in North Eurasia earthquakes source-sites versus specific seismic energy». Geosistemy perehodnykh zon = Geosystems of Transition Zones, 2021, 5(1), pp. 55-59. (Russ. and Engl.). https://doi.org/10.30730/gtrz.2021.5.1.055-059

Для цитирования: Ребецкий Ю.Л. О некоторых аспектах статьи «О сброшенных напряжениях в очагах землетрясений Северной Евразии и приведенной сейсмической энергии». Геосистемы переходных зон, 2021, 5(1), с. 55-59.

https://doi.org/10.30730/gtrz.2021.5.1.055-059

\section{References}

Gusev A.A. 1984. [Descriptive statistical model of earthquake source radiation and its application to an estimation of shortperiod strong motion]. Volcanology and Seismology, 1: 3-22.

Gusev A.A., Guseva E.M. 2014. Scaling properties of corner frequencies of Kamchatka earthquakes. Doklady Earth Sciences, 458(1): 1112-1115. https://doi.org/10.1134/s1028334x14090062

Kocharyan G.G. 2016. Geomechanics of faults. Moscow: GEOS, 424 p.

Skorkina A.A. 2017. [Study of spectral properties of the Kamchatka earthquakes in the magnitude range of 3-6]: [dis. ... Cand. Sci. (Phys. and Math.)]. Petropavlovsk-Kamchatskiy, $130 \mathrm{p}$. 